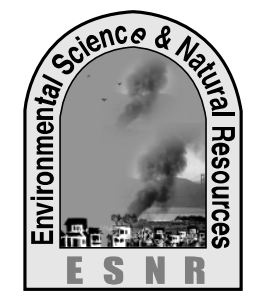

J. Environ. Sci. \& Natural Resources, 7(1): 183-188, 2014

ISSN 1999-7361

\title{
Effects of Microclimatic Parameter on Tea Leaf Production in Different Tea Estates, Bangladesh
}

\author{
M. Ali ${ }^{1}$, M. N. Uddin ${ }^{2}$, M. N. Mobin ${ }^{2}$ and N. Saha ${ }^{1}$ \\ ${ }^{1}$ Department of Forestry and Environmental Science \\ Shahjalal University of Science and Technology, Sylhet \\ ${ }^{2}$ Department of Environmental Science and Resource Management \\ Mawlana Bhashani Science and Technology University, Tangail
}

\begin{abstract}
The tea industry of Bangladesh is one of the most important foreign exchange earner and source of income. Sylhet, the northeastern divisional city of Bangladesh, is the major tea-producing region of the country. For this reason the study area was selected in Sylhet district to assess the pattern and causes of fluctuation on tea leaf production in selected tea Estates and the impact of micro-climate change on the productivity of tea leaf. The yield of tea is greatly influenced by microclimatic parameter of a region especially rainfall, temperature. Scanty rainfall causes irreparable losses because irrigation is seldom used on tea plantations. On the other hand, heavy rains erode top soil and wash away fertilizers and other chemicals. An analysis of the results of field experiments with weather data shows that increase highest tea leaf production per hectare lies on $4000 \mathrm{~mm}$ to $4600 \mathrm{~mm}$ rainfall. Heavy or scanty or delayed rainfall adversely affected the growth and yield of tea. It is observed that tea leaf production is slightly increased with increase in total annual rainfall. The temperature and humidity have no direct effect on tea leaf production. It may largely depend on soil quality and solar radiation. Loobacherra tea estate produces high amount $(1838.70 \mathrm{~kg}$ ) of tea leaf per unit area, on the other hand, Lackatoorah tea estate produce lowest amount $(682.31 \mathrm{~kg})$ of tea leaf. Further study is needed to identify the cause of variation of tea leaf production in different tea estate. Awareness should be rise on micro-climate change amongst the planter, estates and worker groups for the maximum production of tea leaf.
\end{abstract}

Key Words: Micro-climate, Rainfall, Tea production, Temperature

\section{Introduction}

Tea (Camellia sinensis L.) is a unique crop relative to any others typical crop due to its cultivation, harvesting system and climate vulnerability. This type of crop shows wide adaptability and grows in a range of climates and soils in various parts of the world (Hamid, 2006). The art of tea cultivation in Bangladesh began over a century and a half ago in the 1840s near the Chittagong Club and first tea garden for commercial purpose was established at Malnicherra in Sylhet in 1854 (Redowan and Kanan, 2013). Its commercial production began shortly thereafter in 1857 (Nasir and Shamsuddoha, 2011). At present there are 163 tea gardens in the country (BTD, 2012). Bangladesh is the world's 10th-largest tea producer and fifteen number exporters and sixteen number consumers in the world (BTD, 2012).

The role of Bangladesh tea industry in global context is insignificant. It is only $1.68 \%$ of the global tea production and $0.58 \%$ of the world tea export (BTD, 2012). It seems that its export is gradually declining. If this trend continues, Bangladesh will turn into a tea importing country by 2015 (BTRI, 2012 and Mahmud, 2004).Tea plants are highly susceptible to drought and will not thrive well when moisture is limiting. The seasonal monsoons, of course, also greatly affect the quality of tea (Anon. 1996; Hicks 2001).

The growth of plants is controlled by the availability of photosynthesized carbohydrates. Since both rainfall and sunshine are needed for photosynthesis an empirical expression is proposed which relates vegetative growth to the product of rainfall and bright sunshine hours over a specified period. Tea is a crop in which the yield is entirely vegetative and harvested throughout the year. Being a rain fed plantation crop in Sylhet, tea depends greatly on weather for optimal growth. Therefore, changes in weather conditions would undoubtedly affect tea production. The relationship between tea yield and weather has been discussed by many researchers (Carr and Stephens, 1992).

The daily independent news paper reported on tea production as scanty rainfall likely to hit tea production (Saturday, 31 march 2012 author / source: Mahbubur Rahman Ripon). The author mentions that Tea production in Bangladesh could miss the production target by about $25 \%$ this (2012) year owing to a drought-like situation Emdadul Haque, manager of a state-run tea garden at Lakkatura near Sylhet city, said poor rainfall and unusual fluctuation in temperature are the main reasons for the fall in production. This season has experienced at least $50 \%$ less rainfall over the corresponding period of the last season. To achieve the target, each tea garden needs $200-300 \mathrm{~mm}$ of rainfall, but is yet to get $25 \%$ of it since November, 2011. If the drought-like situation continues, he said, production could fall $15-25 \%$ short of the target.

Climatic factors, which include rainfall, temperature, humidity, intensity, and duration of light etc., determine the success of crop production of a region. Of these, perhaps rainfall and 
temperature play the most important role in the development and growth of plants and ultimately yield per unit area.

The main objectives of the present study were to assess the pattern and causes of fluctuation on tea leaf production in selected four tea estates in Sylhet district and to assess the impact of micro-climatic change on the productivity of tea leaf.

\section{Materials and Methods}

\section{Study area}

Sylhet district (small unit of division) is one of the major tea producing areas in Bangladesh which lies in the delta of the Surma River. Geographically Sylhet district is situated between $23^{\circ} 59^{\prime}$ and $25^{\circ} 13^{\prime}$ North latitude and 90 $54^{\prime}$ and 92 $29^{\prime} 50^{\prime \prime}$ East longitude whereas the Burjan, Lackatoorah, Malnichera and Loobacherra tea estates are in the north-eastern part of this district was selected for study area. Beside scenic tea plantations, Sylhet district is most significant area for lush green tropical forest, natural waterfall, green hillock etc. This beautiful scenery always attract national and international tourist to visit Sylhet district. (Banglapedia, 2006)

\section{Materials and Methods}

North-eastern region of Sylhet district is the major tea leaves producing zones along with other agricultural crops due to its climatic condition and geographic position. Therefore, this area was selected purposively to conduct this study. An exploratory survey on Lackatoorah, Burjan, Malnichera and Loobacherra tea gardens were done to collect information on the fluctuation pattern of tea leaf production and changing impacts of microclimatic parameters (rainfall, temperature and humidity) on tea leaf yield. The climatic data of Sylhet district was collected from the Bangladesh Meteorological Department (BMD) and tea production, rainfall data were collected from the selected tea estates and plantation and other time series data was explored from the web site of Bangladesh tea board, the different statistical year book of Bangladesh, BBS. The published data of Lackatoorah, Burjan, Loobacherra and Malinichara tea estates were collected from their administrative office and from the Banglapedia. This study was carried out over a period of six month ranging from January 2012 to June 2012. The data was analyzed graphically by using MS Excel.

\section{Results and Discussion}

\section{Pattern of tea leaf production in selected tea estates}

Production and quality of tea leaf in the selected four tea estates was different. The maximum average (for one year) tea leaf production was found in Loobacherra tea estate $(1835.7013 \mathrm{~kg} / \mathrm{ha})$ and lowest was found in Lakkatoora (682.30811 $\mathrm{kg} / \mathrm{ha}$ ). Production of others two estates Burjan and malnichara was $877.8412 \mathrm{~kg} / \mathrm{ha}$ and 1367.3418 $\mathrm{kg} / \mathrm{ha}$ respectively (Fig: 2). This variation may be due to the soil property and management potentiality of these tea estates. In favor of the maintenance of good quality tea it is required to collect one bud and two leaves (Hays, 2008) but in the field observation it is noticed that, in Loobacherra tea estate collected more than two leaves and a bud. Thus the quantity may increase but the quality of tea may hamper.

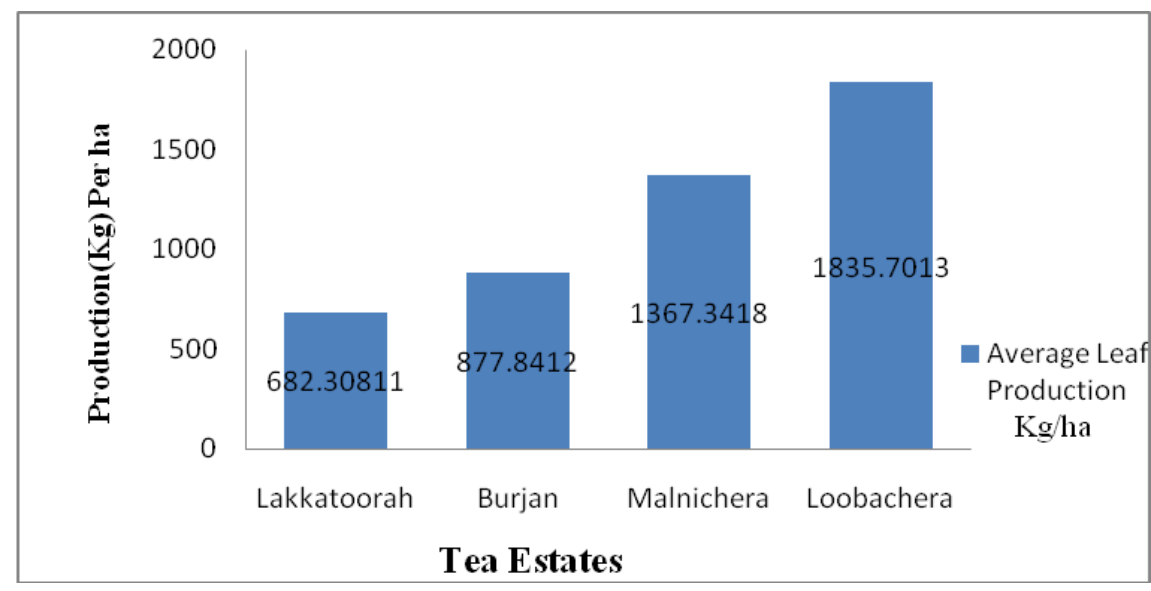

Fig. 1: Tea leaf production per hectare in selected four tea estates

Effects of microclimatic parameter on tea leaf production

Microclimate has large impact on tea leaf production. The seasonal monsoon also greatly affects the tea leaf production (Anon, 1996; Hicks, 2001). In the selected tea estates there was significant relationship with microclimates and tea leaf production.

\section{Effect of rainfall on tea leaf production}

Rainfall was positively related with tea leaf production in Lackatoorah and Burjan tea estate. In the previous 10 years, the minimum rainfall was 
recorded $3132.24 \mathrm{~mm}$ whereas the maximum rainfall was recorded $5523.76 \mathrm{~mm}$ for Lackatoorah tea estate (Fig: 2. a). However, in the last 10 years the minimum rainfall was recorded as $3070.22 \mathrm{~mm}$ for Burjan tea estate while the maximum rainfall was recorded as $5050.95 \mathrm{~mm}$ (Fig: 2. b). The tea leaf production and rainfall in Loobacherra tea estate was moderately correlated and had positive influence on each other. In the past 10 years, the minimum rainfall in Loobacherra tea estate was $3314.54 \mathrm{~mm}$ where the maximum rainfall was $5398.77 \mathrm{~mm}$. In this tea estate the per unit area production was highest among the four tea estate. The soil property and other extraneous factor played positive role for tea leaf production. On the other hand for good quality tea one bud and two leaves are generally collected, but in the field observation it found that more than two leaves including buds were collected from this tea estate. Malnichera is the oldest tea estate in Bangladesh where there was less fluctuation of tea production per unit area. In Malnichera tea estate the rainfall

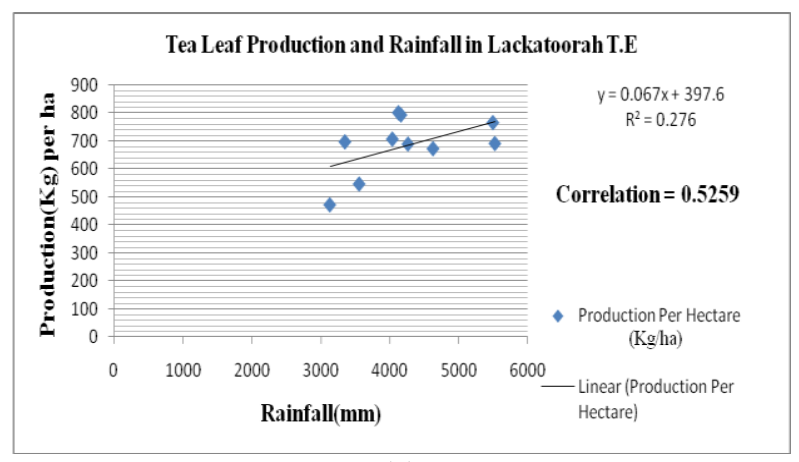

(a)

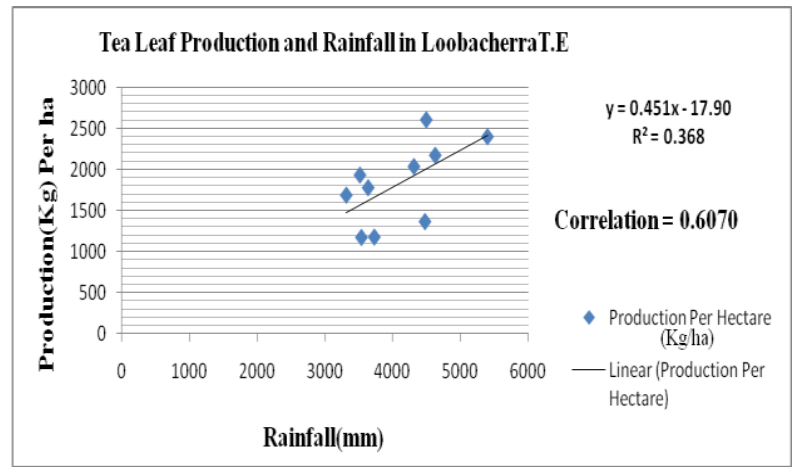

(c) was positively related with tea leaf production. In last 10 years the minimum rainfall was recorded as $3132.87 \mathrm{~mm}$ whereas the maximum rainfall was recorded as $4692.88 \mathrm{~mm}$ (Fig: 2. d). Tea leaf production was slightly increasing with increasing rainfall. The production was fluctuating in the same range of rainfall. It might be potential of the management and other extraneous factors like intensity of sunlight, distribution of yearly rainfall etc. The maximum tea leaf production per hectare of the Lackatoorah tea estate was $791.82 \mathrm{~kg}$ which lies in the rainfall $4163.21 \mathrm{~mm}$ (Fig: 2 . a) and for the Burjan tea estate it was $1059.91 \mathrm{~kg}$ with maintaining rainfall $4666.13 \mathrm{~mm}$ (Fig:2. b). The maximum tea leaf production of other two tea estates namely Loobacherra and Malnichera was $2605.61 \mathrm{~kg} / \mathrm{ha}$ and $1563.32 \mathrm{~kg} / \mathrm{ha}$ with maintaining rainfall $4495.22 \mathrm{~mm}$ and $4692.88 \mathrm{~mm}$ respectively (Fig: 2. c, d). The average rainfall of Lackatoorah, Burjan, Malnichera and Loobacherra tea estates are 3764.674mm, 3934.926mm, 4258.091mm, 4274.65mm respectively (Fig: 2 . e).

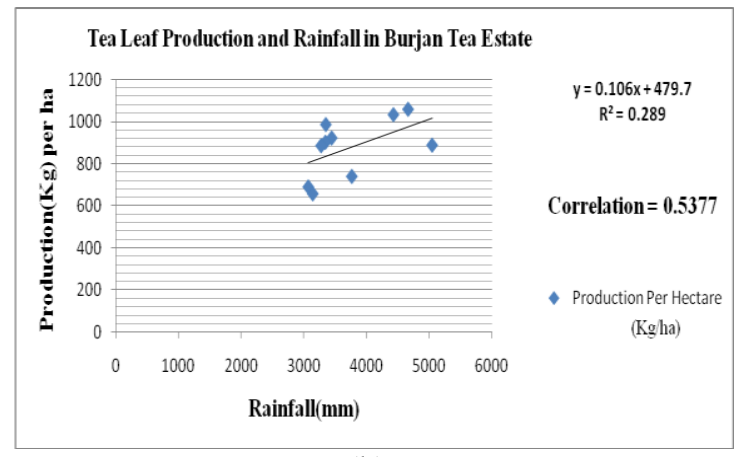

(b)

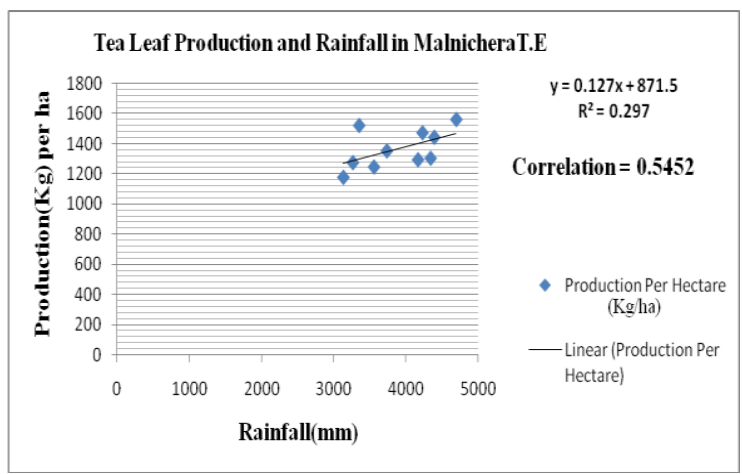

(d)

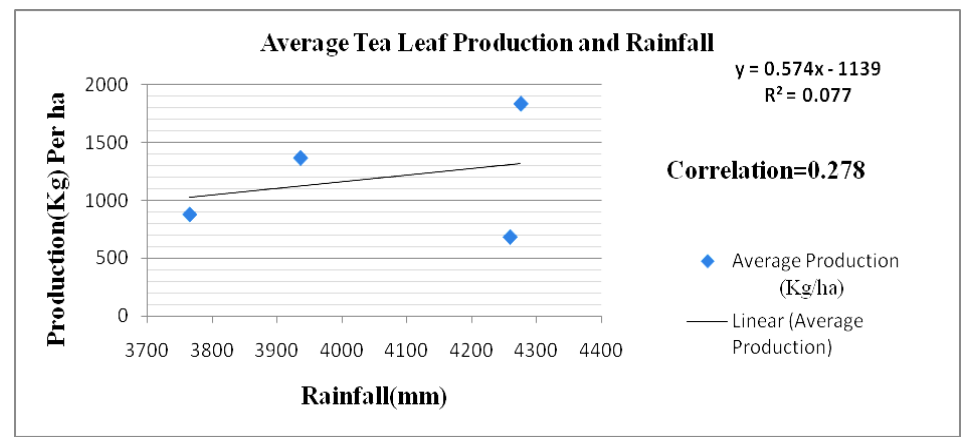

(e)

Fig 2: Relationship between tea leaf production and rainfall in different tea estates 
Effect of temperature on tea leaf production Temperature did not show any significant relationship with tea leaf production of the selected four tea estates (Lackatoorah, Burjan, Loobacherra and Malnichera) (Fig: 3. a, b, c, d).

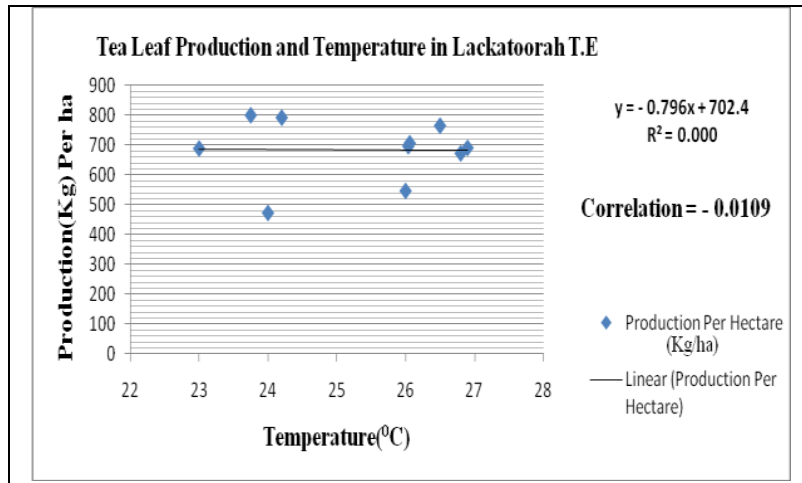

(a)

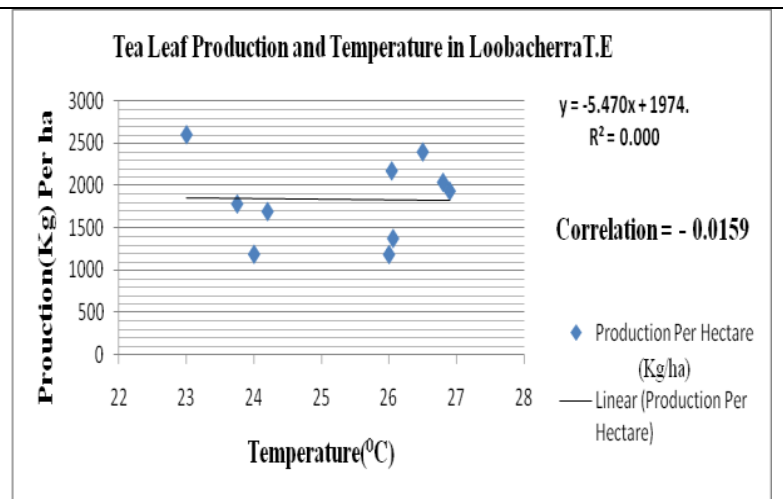

(c)

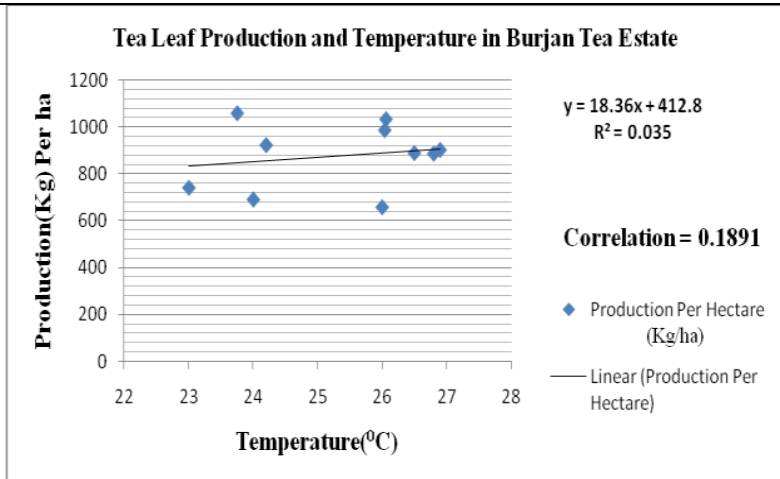

(b)

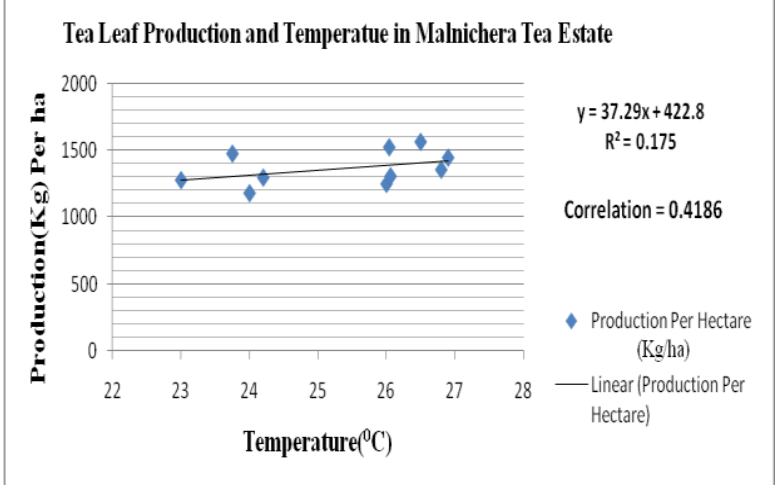

(d)

Fig 3: Relationship between tea leaf production and temperature in different tea estates

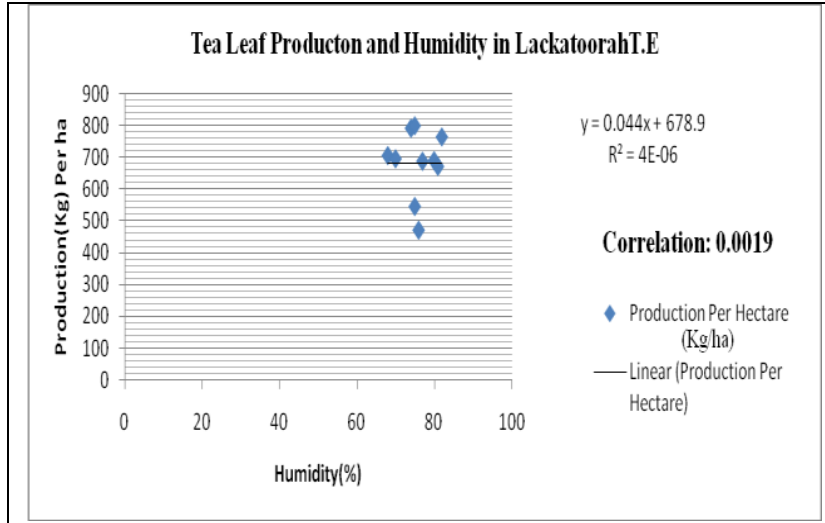

(a)

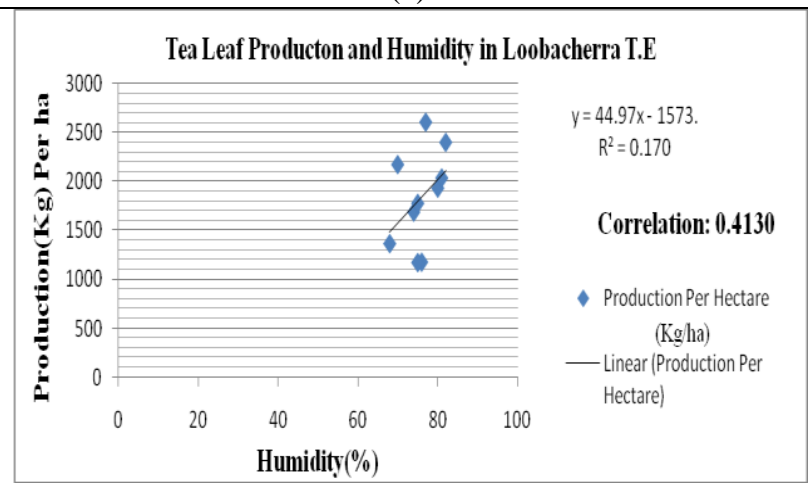

(c)

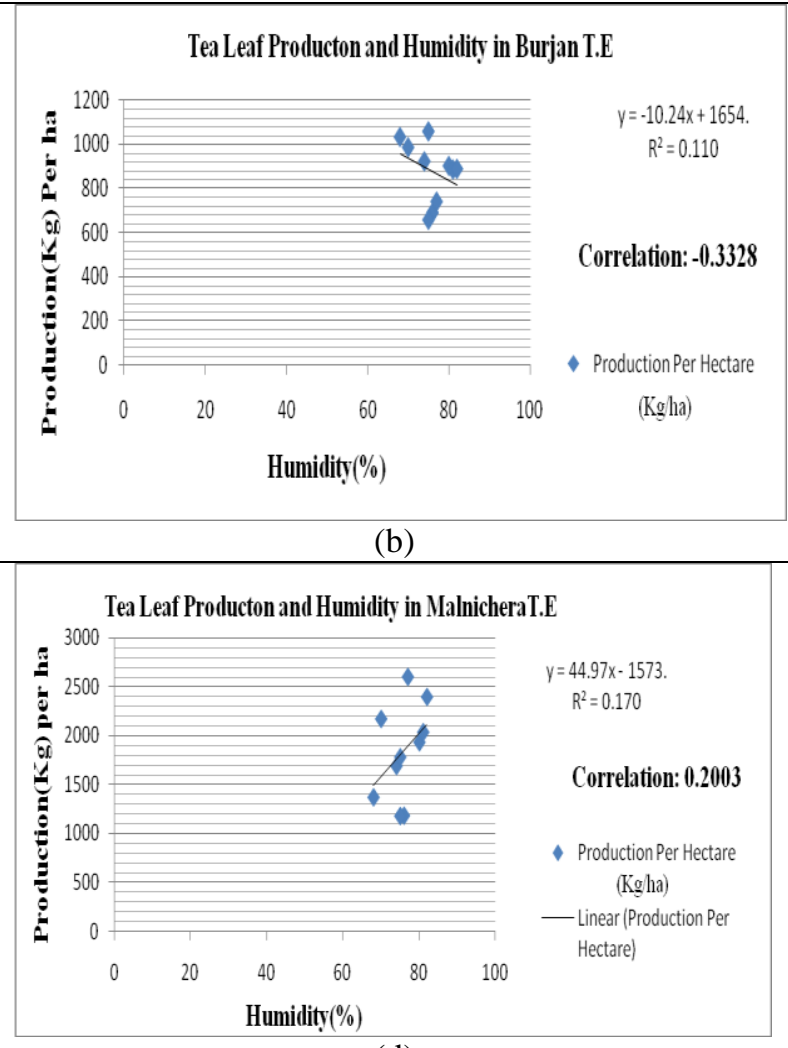

(d)

Fig. 4. Relationship between tea leaf production and humidity in different tea estates 
Hassan et al. (1965) reported after their researches that tea being a perennial crop has wide range of tolerance as it grows between sea level and altitudes of over $2000 \mathrm{~m}$ and as much as $30^{\circ} \mathrm{C}$ or even more and south of equator but the monsoon areas of south east Asia are found to be the best suited. Under north-east Indian conditions an optimum of 30 to $35^{\circ} \mathrm{C}$ is generally considered ideal (Hadfield 1968). In Lackatoorah, Burjan, Loobacherra and Malnichera tea estates there is no significant relation between tea leaf production and temperature. The existing temperature is suitable for tea leaf production in these tea estates. The highest production lies in $\left(23-25^{\circ} \mathrm{C}\right.$. Tea leaf production does not respond in relation to temperature. It is because the amount of rainfall in different tea estates in Sylhet is high.

\section{Effect of humidity on tea leaf production}

In the selected four tea estates (Lackatoorah, Burjan, Loobacherra and Malnichera) humidity did not show any significant relationship with tea leaf production (Fig: 4. a, b, c, d).

The rate of evaporation would increase in a warmer climate, which would lead to an increase in global precipitation of $2-2.5 \%$ per $1{ }^{\circ} \mathrm{C}$ warming. Higher latitudes in the Northern Hemisphere are expected to experience above-average increases in both temperature and precipitation (Mahlman J.D, 1997). Humidity is increase with increase in temperature and precipitation. In the selected four tea estates in Sylhet district there is suitable rainfall and temperature. Thus the humidity is also perfect for tea leaf production. Hence it has no direct effect on tea leaf production. In the selected four tea estates it is observed that the per unit tea production in independent about mean annual humidity. If humidity increases the rate of evapotranspiration is decreases and conversely the rate of evapotranspiration is increases with decrease of humidity in the air. The average humidity in Sylhet lies in $75.8 \%$ of last 10 years.

\section{Conclusions}

The study provides evidence that ultimate per hectare tea leaf production is slightly increasing in different tea estates of Sylhet district due to increased rainfall. Heavy or scanty or delayed rainfall adversely affects the growth and yield of tea but it has been found that tea leaf production is slightly increasing with increase in annual rainfall and the production per unit area is highest at the $4000 \mathrm{~mm}$ to $4600 \mathrm{~mm}$ rainfall. Temperature and humidity has no direct effect on tea leaf production in Sylhet region. These study shows that mean annual rainfall and yield per hectare is positively correlated. There are significant uncertainties in the climatic parameters. The present study suggests that if microclimate changes due to low rainfall and significant increase in temperature will be resulted in a significant loss of yield of tea leaf production.
Moreover, because of the rapid change in the land use pattern through increased urbanization and other anthropogenic activities, tea production is also hampered enormously. In the selected four tea estate it is observed that tea production per unit area in Loobacherra is much higher than other tea estates. Other than rainfall it is also due to the different management potentiality and effect of other extraneous factors like soil properties, light intensity and erosion.

\section{References}

Annual report, 1985. Bangladesh Tea research Institute.

Annual report, 2000. Bangladesh Tea research Institute

Anon, 1996. Tea from Sri Lanka. Sri Lankan Tea Board, Colombo, Sri Lanka.

Bangladesh Tea Board, $6^{\text {th }}$ May, 2009. BBS/UNDP, 2005. Composition of Environmental Statistics of Bangladesh. 2005, Bangladesh Bureau of Statistics; Planning Division, Ministry of Planning, Government of the Peoples republic of Bangladesh, Dhaka, Bangladesh. 419 p.

BCAS, 1994. Vulnerability of Bangladesh to climate change and sea level rise: concepts and tools for calculating risk in integrated coastal zone management, Technical Report, Bangladesh Center for Advanced Studies, Dhaka. 1(2):

Bekhit, M.Y. 2006. Levels of Essential and NonEssential Metals in Leaves of the Tea Plant (Camellia sinensis L.) and Soils of Wushwush Farms, Ethiopia. http://etd.aau.edu.et/dspace/bitstream/123 456789/307/1/Michael\%20Yemane.pdf accessed 10 July 2012.

BTD (Bangladesh Tea Board), 2012. http://www.Teaboard.gov.bd/ accessed 25 June 2012.

BTRI (Bangladesh Tea Research Institute), 2012. Brief note on tea culture for the BTRI annual report, Shromongal, Bangladesh.

Carr, M.K.V. and Stephens, W. 1992. Climate weather and the yield of tea, in: Tea: Cultivation to Consumption, Willson K.C. and Clifford M.N. (eds), Chapmann and Hall, London, pp. 87-135.

Chomchalow, N. 1996. Herbal Tea, an Editorial. NANMAP-17, February 1996, FAO/RAP, Bangkok, Thailand.

Eden, T.1976. The Chemistry of the tea leaf and of its manufacture, $3^{\text {rd }}$ edition@ Longman Group Limited, London 153-65. 
Goudriaan J, Zadoks JC. 1995. Global climate change: modelling the potential responsesof agro-ecosystems with special reference to crop protection. Environ. Pollut., 87: 215-24

Hadfield, W. 1968. Leaf temperature, leaf dose and productivity of the tea bush. Nature, 219: 282-84.

Hamid, F. S. 2006. Yield and Quality of Tea under Varying Conditions of Soils and Nitrogen Availability. Pakistan Research Repository, Higher Education Commision Pakistan.http://eprints.hec.gov.pk/2348/1/2 203.htm accessed 10 July 2012.

Hasan, K.A.; Chaudhury, S.H. and Halim, A. 1965. Effect of climate factors on the yield of tea. Tea J. Pak. 3(1), 19-26.

Hays, J. 2008. Tea cultivation and production. http://factsanddetails.com/world.php?itemid =1565/ accessed 16 May 2012 .

Hicks, A. 2001. Review of Global Tea Production and the Impact on Industry of the Asian Economic Situation. AU J.T. October. Also in: Asian Int. Tea Conf., '98, Singapore, 1-2 October 1998. 5(2):

Idso, K.E. and Idso, S.B. 1994. Plant response to atmospheric $\mathrm{CO}_{2}$ enrichment in the face of environmental constraints: a review of the past 10 years' research. Agric. For. Meteorol., 69:153-203

Islam, G.M.R.; Iqbal, M.; Quddus K.G and Ali, M. Y. 2005. Present status and future needs of tea industry in Bangladesh. Proc. Pakistan Acad. Sci., 42(4): 305-314.

Mahlman, J.D. 1997. Uncertainties in projectionsof human-caused climate warming. Science 278: $1416-17$

Mahmud, M. 2004. Tea in a New Brew. The Daily Star, p 1, Retrieved January 5, 2006, from http://www.thedailystar.et/2004/01/05/ d4010501022.html

Mondal, T.K; .2004. Plant Cell Tissue Org Cult, Netherlands, 76:195-254.

Monjur, M. 2004. Tea in a New Brew. The Daily Star (Bangladeshi National News Paper), January 5. 4.
Nasir, T. and Shamsuddhoa, M. 2011. Tea production, Consumption and Exports: Bangladesh Perspective. International Journal of Education Research and Technology 2(1): 68-73.

Othieno, C.O.; Stephens, W. and Carr, M. K. V, 1992. Yield variability at the Tea Research foundation of Kenya. Agricultural and Forest Meteorology 61: 237-252.

Owuor, P.O.; Wachira, F. N. and Ngetich, W. K. 2010. Influence of region of production on relative clonal plan tea quality parameters in Kenya. Food Chemistry 119:11681174.

Redowan, M. and Kanan, A.H. 2013. A Study on Maximization of Land Use with Associated Crops Other Than Tea and Management. Int. J. of Ecol. and Devt., 25 (2): 57-70.

Stephens, W.; Othieno, C.O. and Carr, M.K.V. 1992. Climatic and weather variability at the Tea Resaerch Foundation of Kennya. Agricultural and forest Meteorology 61: 219-235.

The daily independent news paper, Saturday, 31 March 2012.author / source: Mahbubur Rahman Ripon).

Waheed, A.; Hamid, F. S.; Ahmed, H.; Aslam, S.; Ahmed, N. and Akbar, A. 2012. Different climatic data observation and its effect on tea crop. J. Mater. Environ. Sci., 4(2):299308.

Bhatt, V. 2012. A global study report on revitalizing Indian tea export in Russia. http://www.gtu.ac.in/ABP/Final\%20Repor ts $\% 20$ for $\% 20$ Upload $/ 807 \% 20$ \%20Russia.pdf, accessed 10 May 2012.

Sengupta, B.; Ansar, P. M.; Mahwa, R. S.; Karform, H. K.; Gupt, S. K. and Jwala, V. H., 2007. Comprehensive Industry Documenton Tea Processing Industry. http://www.cpcb.nic.in/newitems/21.pdf, accessed 05 June 2012. 